\title{
SURVEY AND POPULATION STUDIES ON INSECTS BY USING PITFALL AND STICKY TRAPS AT IBEX RESERVE NATIONAL PARK, HUTET BENI TAMIM, SAUDI ARABIA
}

\author{
ALI ABDULLAH ELGHARBAWY
}

Plant Protection Dept. College of Food \& Agric. Sciences, King Saud Univ. P.O. Box 2460, Riyadh 11451, Saudi Arabia, Zoology department, Faculty of Science, Al-Azhar University, Cairo, Egypt

\begin{abstract}
A survey together with studies on the population densities and relative abundance of insects and species richenes at Ibex Reserve National Park, Western Hutet Beni Tamim, $180 \mathrm{Km}$. S. Riyadh in two areas (Protected area and non protected area) during one whole year from May, 2007 to the end of April, 2008, using pitfall and sticky traps.

The survey revealed the presence of fifty three species belonging to thirty six genera, of fifteen families under six orders (Coleoptera, Diptera, Hemiptera, Hymenoptera, Mantodea and Orthoptera). A total number of 1033 insects was obtained throughout the year. The largest numbers were observed during June, December and April. Also the largest number of species was belonging to the order Coleoptera (28 species), followed by the hymenopterans (15 species). Other orders were represented by varying number of species.

The coleopterans were found to be the most abundant and dominant, constituting the majority of the catch (882 individuals, representing $39.9 \%$ of the total catch), followed by hymenopterans (121 individuals, constituting 11.7\% of the total catch). Insects of the other orders were less abundant and were represented by small numbers of individuals.

Thirty nine species belonging to twenty six genera of eleven families and four orders which were obtained throughout the year were collected from the protected area, while forty species belonging to twenty six genera of ten families and five orders were collected from the non-protected area.
\end{abstract}

\section{INTRODUCTION}

Survey, population densities, fluctuations and relative abundance are of significant value to give guide for further faunal studies. Two of the most convenient methods of carrying out such studies are by pitfall traps and sticky traps.

In Saudi Arabia, Al Maqooshy (1996) surveyed the aphids in Riyadh region, recording 18 species. Also, Al Ahmad (1989) surveyed the scale insects in the same region and studied the population dynamics and natural enemies. Ayoub (1959) discussed the insect pests of Saudi Arabia together with recommendations for their control. Al-Menshawy and Hejazy (2001), Issa and Helal (2000), Ali and El Saedy (1999), AlRajwy (1998), Gafaar (1995) and Hamad et al. (1965) surveyed the insects in some Arabian regions.

Hanna (1963 and 1969), Al-Akkad et al. (1997), Al-Gammal et al (1999) and Badr et al., (2001) reported similar studies about some insect groups. The ecological studies of insects, e.g., Hafez and Bishara (1961); Hanna (1973); Alfieri (1976); Helal (1977); Sharaf El-din (1981); Badr (1985); Salem et al. (1985); Shein- ishen et al. (1985); Amin et al (1985); Salem et al. (1986); El-Sayed (1987); Ali and Ibrahim (1988); Shah and Garg (1988); Bebars (2000); Abdel-Dayem et al. (2003); and Morsi and ElGharbawy (2006).

The present work was carried out by using pitfall and sticky traps, to survey and study the population density, relative abundance and fluctuation population of insects in two localities at Hutet Beni Tamim, Saudi Arabia.

\section{MATERIALS AND METHODS}

This study was conducted for surveying and studying the insect population in Ibex Reserve National Park at Huttet Beni Tamim in central Saudi Arabia throughout a whole year (May, 2007- April, 2008). The major plant species in this area are Calotropis procera, Anvillea radiate, Cucumis prophetarum, Citrullus colocynthis, Fagonia bruguieri, Fagonia bruguieri, Lycium shawii and Panicum turgidum. Two locations were selected for the study (protected and non protected). In each location ten pitfall traps made of water plastic bottles, ca. 1.5 liters, were set up under trees in random at suitable distances and three sticky traps made of yellow 
plastic rectangular pieces $(45 \mathrm{X} 20 \mathrm{~cm})$, painted with sticky nontoxic glue were hanged on three distant trees. These traps were collected every two weeks.

Insects were removed carefully from the traps, then sorted, identified, counted and recorded. Data of their annual numbers and percentages of abundance were provided. Calculated Meteorological data as shown in table (1).

Table (1) Meteorological data of average monthly temperature and average monthly humidity during the period of the study.

\begin{tabular}{|c|c|c|}
\hline Months & $\begin{array}{c}\text { Temperature } \\
\text { (Avg.) }\end{array}$ & Humidity(Avg.) \\
\hline December 2006 & 19.4 & $59.94 \%$ \\
\hline January 2007 & 19.5 & $59.92 \%$ \\
\hline February2007 & 1904 & $31.11 \%$ \\
\hline March 2007 & 26.3 & $30.13 \%$ \\
\hline April 2007 & 28.4 & $31.23 \%$ \\
\hline May 2007 & 44.3 & $20 \%$ \\
\hline June 2007 & 48.4 & $11.12 \%$ \\
\hline July 2007 & 47 & $10.02 \%$ \\
\hline August 2007 & 35.1 & $21.11 \%$ \\
\hline September 2007 & 32.5 & $19.23 \%$ \\
\hline October 2007 & 27.6 & $22.16 \%$ \\
\hline November 2007 & 22.3 & $47.09 \%$ \\
\hline
\end{tabular}

All taxa (Families, Genera and species) were arranged alphabetically according to their taxonomic position. Insects were identified based on identification keys, materials kept in the insect collection of the Plant Protection Department, College of Food and Agriculture Science, King Saud University and the collection of Regional Centre for Research on Agriculture and Water Ministry of Agriculture, KSA, and by special taxonomists in UK, USA and Egypt.

The obtained materials from this study were deposited in the King Saud University Museum of Arthropods (KSMA), Department of Plant Protection, College of food and Agricultural Sciences, King Saud University.

\section{RESULTS AND DISCUSSION}

The present survey of the insects throughout a full year (May 2007- April 2008) using pitfall traps (PT) and sticky traps (ST) revealed the presence of fifty three insect species within thirty six genera of fifteen families in six orders. These species are alphabetically arranged according to orders, families and species and they are listed with the locality in table (2).
From this table, the order Coleoptera formed the largest number of species (twenty eight species within six families), order Hymenoptera (fifteen species of three families), order Diptera (four species of three families), order Hemiptera (four species of one family) Orthoptera (one species of one family) and Mantodea (one species of one family)

In the protected area (P), 683 insects represented thirty nine species, twenty eight genera, eleven families and four orders were collected, while in non-protected area (NP) 350 insects represented forty species, twenty six genera, ten families and five orders. The total number of trapped insects by sticky traps was 27 individuals, represented ten species, eight genera, five families and three orders. The trapped insects by pitfall traps collected were 1006 individuals, represented forty three species, twenty eight genera, ten families and four orders.

The data indicated that the total number of insects was 1033 individuals, the largest number of insects was obtained during June, December and May (191, 125and 105 individuals, respectively), while the relatively lowest numbers were during January, February, March and October (28, 37, 46 and 60 individuals, respectively). Relatively large numbers of insects were collected during April, November and May (107, 92 and 86 individuals, respectively). Relatively small numbers were collected during, September and August (75 and 81 individuals, respectively).

The largest number of individuals attributed to order Coleoptera (882 individuals, representing $85.38 \%$ of the total annual catch), these insects were highly active and most abundant during the period from March to November with two major peaks of abundance during April and June (104 and 176 insects, respectively), followed by insects of order Hymenoptera (121 individuals, constituting $11.71 \%$ of the total catch). The majority of these insects were trapped during June to November with two major peaks of abundance during July and November (39 and 21 insects, respectively). Orders: Hemiptera, Diptera, Orthoptera and Mantodea were represented by smaller number of individuals $(21,4,3$ and 2 in- 


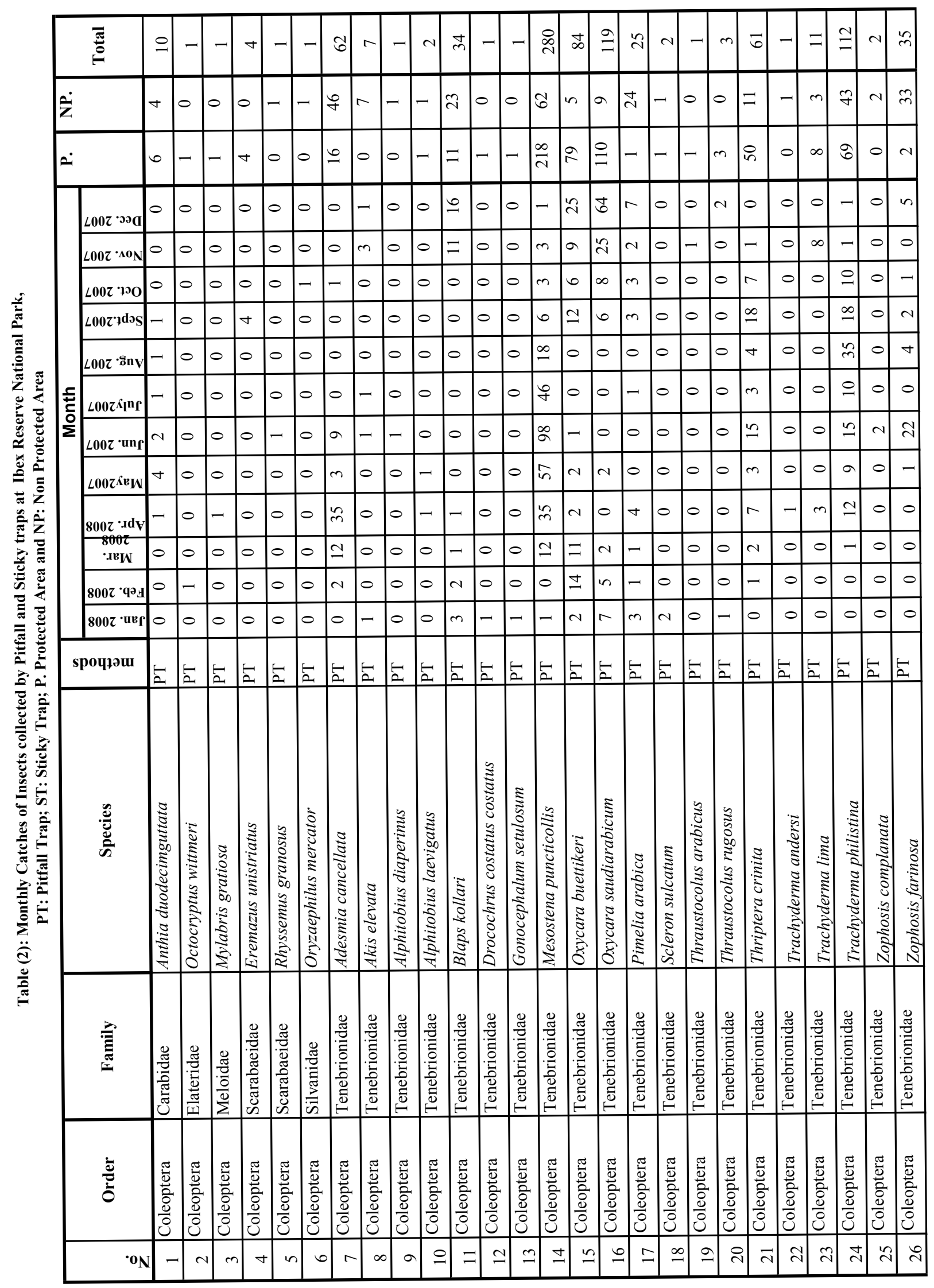




\begin{tabular}{|c|c|c|c|c|c|c|c|c|c|c|c|c|c|c|c|c|c|c|c|c|c|c|c|c|c|c|}
\hline$n$ & $n$ & -1 & - & -1 & - & & & & & & -1 & $=$ & $\checkmark$ & $N$ & 6 & $\forall$ & -1 & $N$ & $\nabla$ & $N$ & -1 & & & -10 & & 官 \\
\hline$\nabla$ & $\simeq$ & 0 & & 0 & & & & & & & - & & & -1 & $m$ & $\infty$ & - & - & $m$ & - & 0 & $\sim$ & & 0 & & \\
\hline-1 & $m$ & -1 & - & -1 & -1 & & & & & & 0 & & & - & $m$ & ల) & 0 & - & - & -1 & - & 01 & -7 & -0 & $c$ & \\
\hline 0 & 0 & 0 & & 0 & & & & & & & 0 & & & 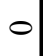 & 0 & 0 & & 0 & 0 & & 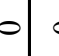 & $c$ & 0 & 0 & - & \\
\hline 0 & 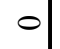 & 0 & & 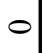 & 0 & & & & 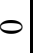 & & 0 & - & & 0 & 0 & $\sigma$ & 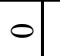 & 0 & 0 & 0 & 0 & 0 & - & 0. & -1 & $p$ \\
\hline 0 & 0 & 0 & & 0 & 0 & & + & & 0 & & 0 & 0 & $n$ & 0 & -1 & 0 & 0 & 0 & 0 & 0 & 0 & 0 & 00 & 0.0 & c & 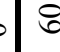 \\
\hline 0 & $\sim$ & 0 & 0 & 이 & 0 & & 0 & & 0 & 0 & 0 & 0 & 0 & - & -1 & 0 & 0 & 0 & -1 & 0 & 0.7 & -0 & 00 & 0 & 0 & $p$ \\
\hline 0 & 0 & 0 & & 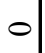 & 0 & & & & & & -1 & & 5 & 0 & $\sim$ & $\nabla$ & - & - & $\sim$ & - & - & - & 0 & 0 & - & - \\
\hline 0 & - & 0 & $c$ & - & 0 & & & & & - & 0 & & 0 & - & $\sim$ & $m$ & 0 & 0 & -1 & -1 & 0 & 0 & 00 & 0 & o & , \\
\hline$\sim$ & $\infty$ & -1 & - & o & - & & & & $c$ & $c$ & 0 & & $m$ & - & 0 & $\nabla$ & 0 & - & 0 & 0 & 0 & 0. & -0 & 00 & & $p$ \\
\hline$m$ & - & 0 & 0 & 0 & 0 & 0 & $c$ & & & 0 & 0 & & 0 & 0 & 0 & 0 & 1 & 0 & 0 & 0 & 0 & 0 & 00 & 0 & & $b$ \\
\hline 0 & - & 0 & 0 & 0 & 0 & & & & & 0 & 0 & & & 0 & 0 & 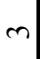 & 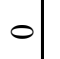 & 0 & 0 & 0 & 0 & 010 & 00 & 0 & & 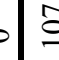 \\
\hline 0 & $\sim$ & 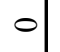 & + & 0 & 0 & 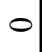 & 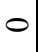 & 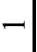 & 0 & 0 & 0 & 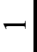 & 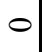 & 0 & 0 & 0 & 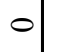 & 0 & 0 & 0 & 0 & 0 & 0 & 0 & & 07 \\
\hline 0 & 0 & 0 & 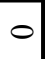 & o & 0 & 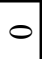 & 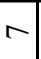 & & & 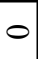 & 0 & 1 & -1 & 0 & 0 & 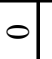 & 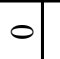 & 0 & 0 & 0 & 0 & 0 & 0.0 & $\begin{array}{lll}0 & 0\end{array}$ & & 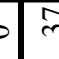 \\
\hline & 0 & 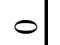 & 0 & 0 & 0 & & 1 & 0 & -1 & & 0 & $\nabla$ & ol & ol & 0 & 0 & ol & & 0 & & & & & -0 & & \\
\hline
\end{tabular}

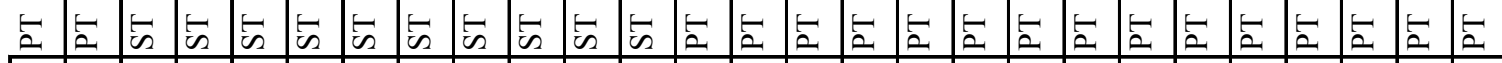

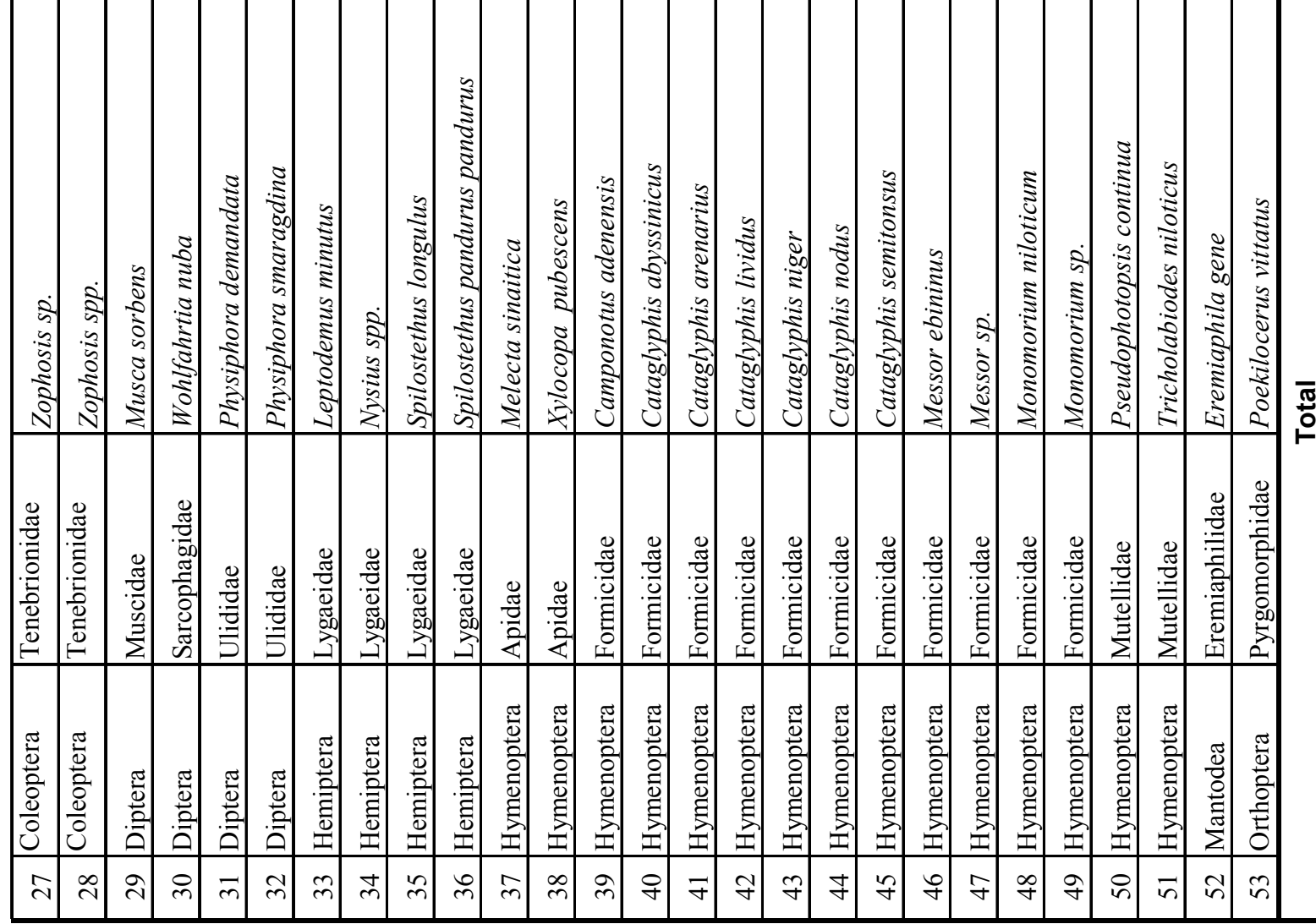


dividuals, constituting $2.03 \%, 0.39 \%, 0.29$ and $0.19 \%$ of the total catch, respectively).

The beetle species, Mesostena puncticollis, was the most abundant and dominant of all species, with a total annual number of 280 individuals, constituting $27.11 \%$ of the total annual catch. Individuals of this species were largely active and most frequent during May and June (57 and 98 individuals, respectively). Oxycara saudiarabicum came next in abundance (119 individuals), active and most frequent during November and December (25 and 64 individuals, respectively).

From the previous data, it is suggested that, the increase of the individuals in June probably due to prevailing climatic conditions were suitable in this month, but they were harsh during other months.

\section{REFERENCES}

Abdel-Dayem, M.S.; El-Hawagry, M.S. and Hassan, S.A. (2003): A review of the Egyptian species of tiger beetles (Coleoptera, Carabidae, Cicindelinae). Bull. Ent. Soc. Egypt, 80: 193-217.

Al-Ahmad, A.M. (1989): Survey of scale insects of certain fruit and shade trees in Riyadh region, with special reference to the study of the population dynamics and natural enemies of the dominant species. M.Sc. thesis, Agriculture college, King Saud University. (125 pp.) (In Arabic).

Al-Akkad, M. K.; Salem, M. M. and Al-Gamal, M. M. (1997): Relative abundance of some coleopterous species attracted to light trap at Al-Arish city, North Sinai, during two successive years. Ann. Agric. Sci., Ain Shams Univ., Cairo, 42 (2): 655 - 664.

Alfieri, A. (1976): Coleoptera of Egypt. Mem. Soc. Ent. Egypte, 5: 362pp

Al-Gammal, M. M.; Salem, M. M. and Sayed, A. A. (1999): Detective survey for the insect fauna of the New Valley, Egypt. Proc. Efflatoun's Conf. of Ent., 1'st. vol., 183198.

Ali, M.A. and Al-Saedy A. (1999): Scientific guide for insect pests and their control. Al-Dar Al-Masreia Al-Lebnaneia. Egypt. 239 pp. (In Arabic).

Ali, M.A. and Ibrahim, I.L. (1988): Prelimenary study on occurrence and abundance of Tropinota squalida Scop (Coleoptera, Scarabaeidae) infesting ornamental plants and fruit crops. Al-Azhar. J. Agric. Res., 9:1-14.

Al-Maqooshy, A. (1996): Survey of aphid insects on ornamental plants in Riyadh city, and the impact of the rates of nitrogen fertilization and irrigation on population density to it. M. Sc. Thesis, Agriculture Faculty, King Saud University. 112 pp. (In Arabic).

Al-Menshawy, A. and Hejazy, E. (2001): Pests of insects and animals and its control. $1^{\text {st }}$ ed., Almareef Library. Egypt- 687 pp. (In Arabic).

Al-Rajwy, A. (1998): Applied guide to pest control and plant diseases. Madbolli Library, Egypt. 334 pp. (In Arabic).

Amin, A.H.; Assaggaf, A.I. and Robai, A.A. (1985): Study and relative abundance of some coleopterous insects attracted to a light-trap in Jeddah, Saudi Arabia. Bull. Soc. Ent. Egypt, 66: 299- 317.

Ayoub M. (1959): Insects and Agricultural pests and control method in Saudi Arabia. Dar Al Feekr in Riyadh K $\mathrm{S} A$ (405 pp). (In Arabic).

Badr, S. A.; Salem, M. M. and Badr, M. A. (2001). Population studies on catchs of coleopteous beetles in a light trap at Behaira Governorate, Egypt. Egypt. J. Appl. Sci., 16 (5): 232- 240.

Badr, S.A. (1985): Taxonomical and Ecological studies on some common scarabaeidae in Egypt (Scarabaeidae, Coleoptera) M.Sc. Thesis Fac. Science, Cairo Univ., 244pp.

Bebars, E.A. (2000): Comparative study of the insects diversity and the seasonal abundance of some species in the two different regions in Egypt. M.Sc. Thesis, Fac. of Agric., Al-Azhar Univ., 259pp.

Ellis, J.A.; Walter, A.D.; Tooker, J.F.; Ginzel, M.D.; Reagel, P.F.; Lacey, E.S.; Bennett, A.B.; Grossman, E.M. and Hanks, L.M. (2005): 15 Conservation biological control in urban landscapes: Manipulating parasitoids of bagworm (Lepidoptera: Psychidae). Biol. Cont., 34: 99-107

El-Sayed, E.S. (1987): Studies on the ecology and survey of some insect species in north Sinai by the use of light traps. Ph.D. Thesis, Fac. of Agric. Suez-Canal Univ., 270 pp.

Gafaar, B. (1995): Diseases and insects of vegetables and their control methods. Dar Al Marefa- Syria, 253 pp. (In Arabic).

Hafez, M. and Bishara, I.S. (1961): Studies on the biology and ecology of Pentodon bispinosus Kust. in Egypt. Bull. Soc. ent. Egypte XLIV, 155-157.

Hamad, S.; El-Arossy, H. and Assem, M. (1965): Pests and Vegetables diseases and its control. 1st ed. AlDar AlQawmeia for Printing and Publishing. Egypt, 766 pp. (In Arabic).

Hanna, H. M. (1963). Flight activity of Coleoptera as indicated by a light trap. Bull. Soc. Ent. Egypt, 47, 133 -140 .

Hanna, H. M. (1969). Studies on catches of Coleoptera in a light trap at Assiut. Bull. Soc. Ent. Egypt, 62: 335 345. 
Hanna, H.M. (1973): The nocturnal flight of certain tiger beetles as indicated by three light traps. Bull. Soc. Ent. Egypt, 57: 335-345.

Heinz, K.M.; Parella, M.P. and Newman, J.P. 1992: TimeEfficient Use of Yellow Sticky Traps in monitoring Insect Populations. J. Econ. Entomol., 85(6): 2263- 2269.

Helal, H. (1977): A survey of the coleopterous wood-boring insects in A.R.E. as indicated by infested materials and light traps. The $1^{\text {st }}$ Arab Biological Control. Alex. Oct., 1977.

Held, D.W. and Potter, D.A. (2004): Floral characteristics affect susceptibility of hybrid tea roses, Rosa $\mathrm{x}$ hybrida, to Japanese beetles (Coleoptera: Scarabaeidae). J. Econ. Entomol., 97(2):353-360.

Issa, I. and Helal H. (2000): Modern Methods in study of pests of vegetables, ornamental and wood-trees and its control in Arabic world. Part III. Dar Al-Ketab AlHadeeth. Egypt. 363 pp. (In Arabic).

Moore, R. and Hanks, L. (2004): Aerial dispersal and host plant selection by neonate Thyridopteryx ephemeraeformis (Lepidoptera: Psychidae). Ecol. Entomol. 29, $327-335$.

Morsi, G.A. and El-Gharbawy, A.A. (2006): Survey and Population Studies on Coleopterous Fauna of Northern Sinai and Beni-Suif Governorates Using Light Traps. Al-Azher Bull. Sci., Vol. 17(1): 43- 56.
Salem, M.M.; M.A. Badr; S.H. Moftah; M.A. Rizk and A.A. Oshaibah (1985): Survey and seasonal activity of coleopterous insects as indicated by a light-trap in Dakahliya province, Egypt. Minia. J. Agric. Res \& Dev., 7(1): 149-167.

Salem, M.M.; M.M. Al-Gamal; H.R. Hussein; M.A. Soliman and A.A. Oshaibah (1986): Survey, abundance and fluctuation of coleopterous insects at Noubariah region as indicated by a light-trap. Minia. J. Agric. Res. \& Dev., 8(1): 143-162.

Shah, N.K. and D.K. Garg (1988): Seasonal abundance of white grub beetles on a light trap. Indian J. Eol., 15(1), 105-108.

Sharaf-Eldin, A.A. (1981): The nocturnal activity of some insect orders as indicated by captured in a light trap at Giza region. M.Sc. Thesis, Fac. of Agric., Cairo Univ., 265pp.

Sheinishen, Z.; Shawer, M.B.; Badr, M.A. and Salam, M.M. (1985): A preliminary survey and seasonal abundance of coleopterous insects captured by a light trap in Kafr El-Sheikh, Egypt. Proc., $6^{\text {th }}$ Arb. Pesticide conf. Tanta Univ., 11: 39-48.

Triplehorn, C.A. and Johnson, N.F. (2005): Borror and Delong's Introduction to the study of insects. Seventh edition. Thomson Brooks/Cole., 864 pp.

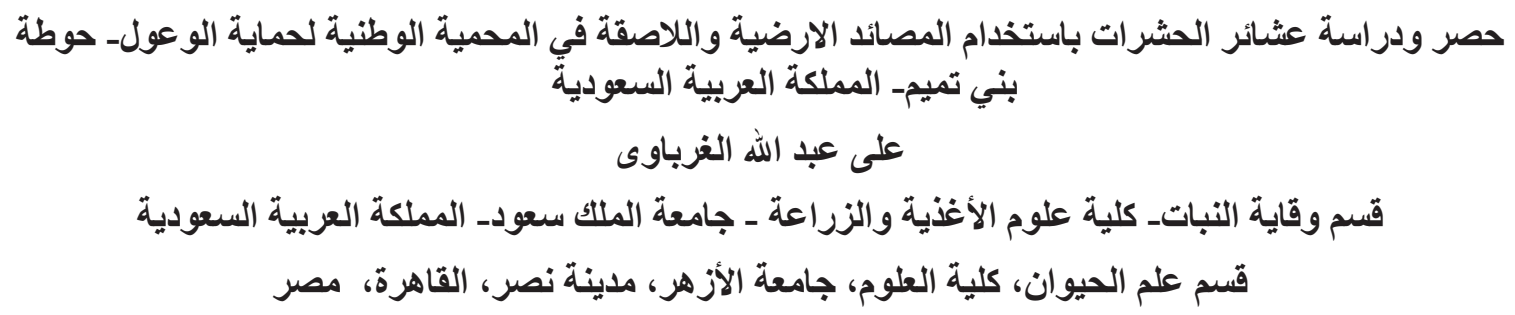

